\title{
Ectoparasites of Birds from a Rice Field in Samarahan Division, Sarawak
}

\author{
NUR ATHIRAH ASRIF, KARIM NURQAMAREENA \& YEE LING CHONG*
}

\author{
Faculty of Resource Science and Technology, Universiti Malaysia Sarawak, 94300 Kota Samarahan, Sarawak, \\ Malaysia \\ *Corresponding author: ylchong@unimas.my; yeelingchong@gmail.com
}

\begin{abstract}
Birds are easily infested with ectoparasites due to their fitness, foraging behaviour, nesting cavities, micro- and macro-habitats. However, the status of ectoparasite infestation on birds in Sarawak is widely unknown. Rice field provides food resources to a variety of birds. This study was conducted to determine the species composition of ectoparasites from birds in a rice field at Kuap Village, Samarahan, Sarawak. A total of 69 birds consists of five species were caught from the rice field and the most common bird species found was the Chestnut Munia (Lonchura atricapilla). From these, 55 were found infested with ectoparasites with the infestation prevalence of $79.71 \%$. A total of 2,513 ectoparasites from eight species were recovered from this study which comprised of six species of mites, one species of soft tick, and one species from the class Insecta. The most dominant ectoparasite species was mite namely, Nanopterodectes sp. with a total of 1,626 individuals. This baseline data on the ectoparasite composition and infestation of birds is important as some of the ectoparasites have the potential in transmitting zoonotic diseases to the farmers working at the rice fields in this region.
\end{abstract}

Keywords: Avian, Chestnut Munia, ectoparasite infestation, paddy plantation, Malaysia

Copyright: This is an open access article distributed under the terms of the CC-BY-NC-SA (Creative Commons Attribution-NonCommercialShareAlike 4.0 International License) which permits unrestricted use, distribution, and reproduction in any medium, for non-commercial purposes, provided the original work of the author(s) is properly cited.

\section{INTRODUCTION}

Rice (Oryza sativa) is a staple food of Asians and represented $35 \%$ of the daily calorie intake of the people in Asia. The production of rice paddy and other correlated harvest activities have been a prominent economic sector and employed billion people in various Asian rural areas (Kevin, 2012). In Sarawak, there are vast varieties of rice with an average annual area of 125,923 ha of rice fields (Department of Agriculture Sarawak, 2016).

In Sarawak, there are 688 species of birds in which 61 are endemics to the state (Phillipps \& Phillipps, 2013). Birds can be found in various types of vegetation such as mangrove, tropical forest and monoculture plantations, including rice fields. A study done by Nur Munira et al. (2014) recorded 5,120 individuals from 67 species of birds that were observed in the rice fields on the northern part of the Peninsular Malaysia. The bird families that were most commonly observed in the rice fields include Ardeidae (29.09\%), Sturnidae (10.15\%) and Hirundinidae (7.86\%) (Nur Munira et al., 2014). Another study done by Makbul and Wong (2016) in Kota Belud Sabah showed that the most abundant species found in wet paddy fields were the Intermediate Egret (Egretta intermedia) and Black-winged Stilt (Himantopus himantopus). Besides, a recent study done by Nurqamareena, Chong, MohdAzlan and Ramji (2018) showed that birds from the family Estrildidae dominated a wet paddy field at Lundu, Sarawak. The diversity and abundances of birds were higher during non-growing periods in temperate zones in which migrant species are often found occupying the rice fields during the non-breeding season (Eadie, Elphick, Reinecke \& Miller, 2008; Fujioka, Lee, Kurechi \& Yoshida, 2010).

Birds harbored a great variety of ectoparasites which may cause negative effects to their fitness (Clayton, Koop, Harbison, Moyer \& Bush, 2010). The common ectoparasites of birds include the biting lice (Mallophaga), fleas (Siphonaptera) and black flies (Simuliidae), hard ticks (Ixodidae), soft ticks (Argasidae) and certain mites (Wamiti, 2014). Ectoparasites are mostly blood suckers while others, such as Ischnocera lice and certain species of mites, subsist on skin components (Hopla, Durden \& Keirans, 1994). A study by Cheke (1972) on birds at Cherangani montane forests in Kenya reported 30 bird species and their associated parasites. In Sarawak, the ectoparasite prevalence and intensity of birds were studied in Matang Wildlife Sanctuary and Gunung Gading National Park (Sodhi, 2002). The threatening status of birds is often correlated to the destruction of habitat as well as parasitism. Koop (2015) stated that bird extinction could be avoided if parasite infestation of bird is reduced by $40 \%$. Albeit this fact, study on the ectoparasite infestation of birds is limited. Parasites however play a prominent role in an ecosystem by shaping the populations and communities of their hosts (Wood et al., 2007). 
Given by the variety species of birds, there might be a lot of the ectoparasites that have not been recorded or described. However, studies on ectoparasites of birds in rice field is still lacking. Therefore, this preliminary study was conducted to determine the prevalence of ectoparasites on birds from a rice field at Kuap Village, Samarahan, Sarawak. This study is crucial as precautions to zoonotic diseases potentially carried by some of the bird ectoparasites that might affect the farmers' health who are working in the rice fields.

\section{MATERIALS \& METHODS}

\section{Study Site}

This study was conducted at a wetland rice field at Kuap Village, which is located in Samarahan Divison, Sarawak, Malaysia $\left(1.51000000^{\circ} \mathrm{N}, 110.57527778 \mathrm{E}\right)$ (Figure 1). Most of the paddy plants were still in the early growing stage with approximately three months of planting. The size of the rice field was 27 ha and located approximately 5 meters from a nearby secondary forest and housing areas. The paddy was mainly planted for self-consumption by the villagers.

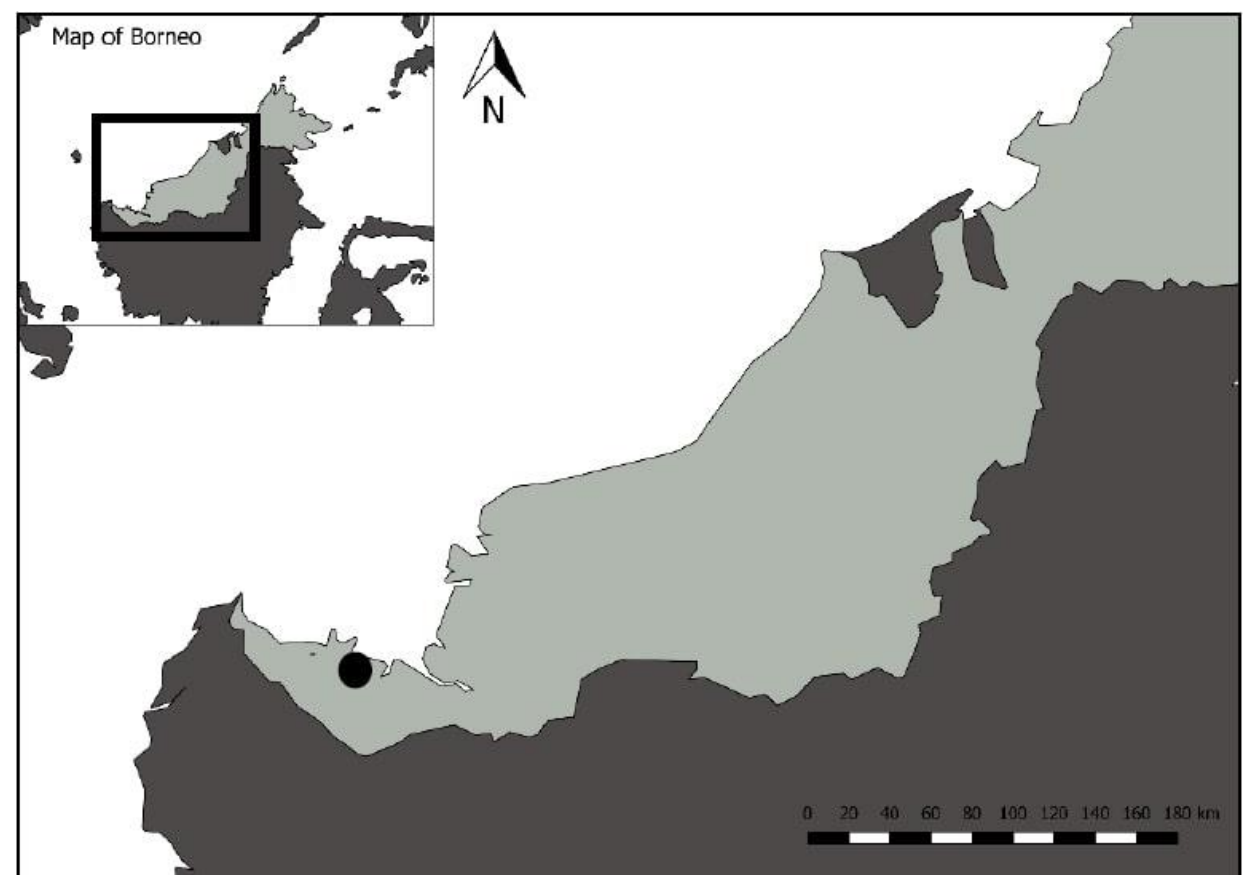

Figure 1. Bird samplings at a rice field at Kuap Village (indicated as black dot) located in Samarahan Division, western Sarawak. The upper left insert indicates map of Borneo.

\section{Bird Sampling}

A total of 30 mist nets were deployed at the study site. Mist nets with the range size of four shelves were erected with poles. It is a passive technique where no aid is used to attract birds into the nets (Wamiti, 2014). Mist nets were deployed randomly and at least $100 \mathrm{~m}$ apart from each other with no vegetation to conceal the nets. The mist netting was scheduled from 0600 hours until $1800 \mathrm{hrs}$. The nets were frequently checked for every two hours by two or more field observers. The overall sampling effort was 1,650 hours.

Birds that were captured in the mist nets were removed and immediately put inside individual cotton cloth bags to avoid the loss of volant parasites (Wamiti, 2014) from transferring among hosts (Clayton \& Walther, 1997). Identification of birds was based on Myers (2009) and Phillipps and Phillipps (2013). For each of the captured birds, the wing length, total head length (skull), and tarsus length were measured using a veneer calipers; while the live weight was recorded using a pesola spring balance; and the primary and secondary feathers molt scores were recorded (Wamiti, 2014). The captured birds were also ringed with a running number for sampling inventory, except for kingfishers.

\section{Collection and Identification of Ectoparasites}

In this study, visual examination method was used for the identification and quantification of ectoparasites on birds. Visual examination was appropriate for relatively small-bodied birds due to their practically few feathers (Wetmore, 1936). The feathers were examined within 10-15 minutes and any ectoparasites observed were removed from the plumage with forceps and immediately transferred into a vial containing $70 \%$ ethyl alcohol (Clayton \& Walther, 2001). The ectoparasites were later brought into the laboratory for processing and identification. 
The parasites were sorted according to their morphologies. Each vial containing the representatives of the ectoparasites were put inside a petri dish and visualized under a stereo microscope ( $0.8 \mathrm{X}$ - 3.5X magnifications). The parasites were quantified and sorted according to their respective morphologies. After sorting, the ectoparasites, mainly mites and lice, were then soaked with lactophenol for clearing at room temperature for at least one day depending on its size. Then each representative of the ectoparasites was mounted with mixture of Canada balsam and xylene medium. Specimen for each species was placed under a glass coverslip for permanent mounts. The slides were left to dry in room temperature for a week to harden the mounting medium. The slide mounting technique was conducted and modified according to Mariana et al. (2005) and Chuluun, Mariana, Ho, and Mohd Kulaimi (2005). Identification of ectoparasites was done using a Motic BA210 compound microscope (4X, 10X, 40X, and 100X magnifications). Ectoparasites that were failed to be mounted due to its minute size were coated in JEOL (JFC1600) Auto Fine Coater and observed using JEOL (JSM6390LA) Automatic Scanning Electron Microscope (ASEM). The ectoparasites were identified to genus levels, and when possible at species levels in compliance to available keys, such as Constantinescu, Chişamera, Mukhim and Adam (2016), Hung (2009), Knee and Proctor (2006) and Martins, Fecchio and Labruna (2014).

\section{Data Analysis}

The number of ectoparasite individuals per host were recorded and the prevalence of ectoparasite infestation on birds (number of birds infested with a particular ectoparasite species from the total number of birds captured) and their ectoparasite mean abundance (number of ectoparasites from the total number of infested birds) were calculated.

\section{RESULTS}

\section{Bird Species Composition}

A total of 69 individuals consists of three families (namely Alcedinidae, Estrildidae and Pycnonotidae) belonging to five bird species were caught and examined for ectoparasite infestation (Table 1). The most common bird family captured was Estrildidae. The most dominant bird species captured was the Chestnut Munia (Lonchura atricapilla) with a total of 39 individuals (56.52\%). Meanwhile, only one individual of Blue Eared Kingfisher (Alcedo meninting) was captured and listed as "Protected" under Sarawak Wild Life Protection Ordinance 1998.

Table 1. Birds captured from a rice field at Kuap Village, Samarahan and the conservation status of bird species according to the IUCN (LC= Least Concerned) and Sarawak Wild Life Protection Ordinance 1998 (SWPO; P= Protected; NL: Not Listed).

\begin{tabular}{lllccc}
\hline Family & Species & Common Name & $\begin{array}{c}\text { No. } \\
\text { individuals }\end{array}$ & $\begin{array}{c}\text { WLPO } \\
\mathbf{1 9 9 8}\end{array}$ & $\begin{array}{c}\text { IUCN } \\
\mathbf{2 0 1 8}\end{array}$ \\
\hline Alcedinidae & Alcedo meninting & Blue-eared Kingfisher & 1 & $\mathrm{P}$ & LC \\
Estrildidae & Lonchura punctulata & Scaly-breasted Munia & 12 & $\mathrm{NL}$ & LC \\
& Lonchura atricapilla & Chestnut Munia & 39 & $\mathrm{NL}$ & LC \\
& Lonchura fuscans & Dusky Munia & 15 & $\mathrm{NL}$ & LC \\
Pycnonotidae & Pycnonotus plumosus & Olive-winged Bulbul & 2 & $\mathrm{NL}$ & LC \\
\hline & TOTAL & $\mathbf{6 9}$ & & \\
\hline
\end{tabular}

\section{Ectoparasite Infestation}

A total of 2,513 individuals of ectoparasites which belonged to three different orders from eight species were collected from the captured birds (Table $2 \& 3$ ). These include six species from the order Astigmata, one species from the order Ixodidae and one species from the order of Coleoptera. The most common ectoparasites found on birds were the feather mites from the family Proctophyllodidae followed by the family Trouessartiidae. The identification for the group of mites from the family of Proctophyllodidae and Trouessartiidae were distinguished by their chelicera, palpus metapodal plate, anal plate and other reliable structures that can be viewed under the compound microscope. For the family of Ixodidae, the species was distinguished by referring to its palpus, anal groove and the posterior margins of the body.

The highest number of ectoparasite individuals with the highest mean abundance were collected from the mite Nanopterodectes sp. while only one individual each were recovered from tick Haemaphysalis sp. and Insect 1 (Table 2 \& 3). Both Blue-eared Kingfisher (Alcedo meninting) and Olive-winged Bulbul (Pycnonotus plumosus) were not infested with any ectoparasites. Chestnut Munia (Lonchura atricapilla) showed the highest ectoparasites infestation among all the five species of birds captured. 
Table 2. Species of ectoparasites recovered from a rice field at Kuap Village, Samarahan.

\begin{tabular}{|c|c|c|c|c|}
\hline Order & Family & Species & $\begin{array}{c}\text { Prevalence } \\
(\%)\end{array}$ & $\begin{array}{c}\text { Number of Ectoparasites/Number of Infested } \\
\text { Birds (Ectoparasite Mean Abundance) }\end{array}$ \\
\hline Ixodidae & Ixodidae & Haemaphysalis sp. & 0.04 & $1 / 1(1.0)$ \\
\hline \multirow[t]{6}{*}{ Astigmata } & Proctophyllodidae & Nanopterodectes sp. & 65.58 & $1628 / 39(41.7)$ \\
\hline & & Proterothrix daberti & 19.42 & $506 / 31(16.3)$ \\
\hline & & $\begin{array}{l}\text { Pterodectes } \mathrm{sp} . \\
\text { (tritonymph) }\end{array}$ & 0.44 & $11 / 2(5.5)$ \\
\hline & Trouessartiidae & $\begin{array}{l}\text { Trouessartia } \\
\text { cyanourepterae }\end{array}$ & 8.24 & $216 / 18(12.0)$ \\
\hline & & $\begin{array}{l}\text { Trouessartia } \\
\text { longidenticulata } \\
\text { constantinescu }\end{array}$ & 1.51 & $38 / 2(19.0)$ \\
\hline & & Trouessartia sp. & 4.74 & $112 / 9(12.4)$ \\
\hline Coleoptera & unknown & Insect 1 & 0.04 & $1 / 1(1.0)$ \\
\hline
\end{tabular}

Table 3. Ectoparasite prevalence of birds collected from a rice field at Kuap Village, Samarahan.

\begin{tabular}{|c|c|c|c|c|c|c|c|c|c|}
\hline \multirow[t]{2}{*}{ Birds Species } & \multirow[t]{2}{*}{$\mathrm{P}(\%)$} & \multicolumn{8}{|c|}{ Number of ectoparasite individuals } \\
\hline & & $\mathrm{T} 1$ & $\mathrm{~T} 2$ & T3 & $\mathrm{T} 4$ & T5 & T6 & $\mathrm{T} 7$ & $\mathrm{~T} 8$ \\
\hline Alcedo meninting & 0 & - & - & - & - & - & - & - & - \\
\hline Lonchura punctulata & 75 & - & 222 & 27 & - & 22 & - & 16 & - \\
\hline Lonchura atricapilla & 87.17 & 1 & 1,350 & 468 & 11 & 194 & 38 & 28 & 1 \\
\hline Lonchura fuscans & 73.33 & - & 56 & 11 & - & - & - & 68 & - \\
\hline Pycnonotus plumosus & 0 & - & - & - & - & - & - & - & - \\
\hline Total & & 1 & 1,628 & 506 & 11 & 216 & 38 & 112 & 1 \\
\hline
\end{tabular}

\section{DISCUSSION}

This study successfully captured high number of bird individuals at a rice field in Kuap Village, Samarahan, western Sarawak. It is comparable to a study done by Nurqamareena et al. (2018) in which 74 individuals of birds were captured at a rice field in Stunggang Melayu Village, Lundu, western Sarawak with the same sampling effort. The high number of captures is most possible explained by the growing phase of the rice plants during bird sampling period as reported by Bambaradeniya, Fonseka and Ambagahawatte (1998). This could be due to the great amount of food resources provided by the rice fields to the birds. Although the number of bird individuals was high, this study shows a low diversity of bird species observed at the rice field possibly due to monoculture plantation such as rice field that acts as a food reservoir for a limited number of bird species with their specific types of diets. A local study done by Avery (1979) suggested that munias have high preferences towards milky rice over ripe rice and common grass in terms of diets. This finding supports that bird species richness and abundance were influenced by local resource availability and vegetation composition (Arthur \& Arthur, 1961; Casas, Darski, Ferreira, Kindel \& Müller, 2016; Cody, 1985). Meanwhile, the abundance of insects at the rice fields was possibly explained by the rice fields that served as an insect breeding place due to their temporary wetland criteria (Nur Munira et al., 2014).

This study shows that ectoparasite infestation on birds was high at this rice field. The birds which heavily infested with ectoparasites were from the family of Estrildidae. According to Diaz-Real et al. (2014), the high infestation of ectoparasites might be related to the pool of exploitable resources such as the bird's body condition and environmental variables. For instance, the host condition may be affected with the weather conditions it has experienced. Besides, Gillespie, Chapman and Greiner (2005) stated that parasites abundance on host can be influenced by host density, intraspecific contact and interspecific contact rates, diet and home range, all of which may be affected by human activities associated to the landscape.

This study shows that the number of recorded mite species were higher than tick species. Mites were found to be less host-specific (hence, generalists). Six ectoparasite species from two families of mites, namely Proctophyllodidae and Trouessartiidae, were commonly recovered from the birds in this study. Nanopterodectes sp. and Trouessartia sp. can be differentiated based on the presence of vertical setae and Solenidion $\sigma 1$ of genu II, in which both structures were present in Nanopterodectes sp. but absent in Trouessartia sp. From these, the highest individuals recorded was Nanopterodectes sp.. Interestingly, this mite species was also commonly found in the 
narrow corridors between barbs on the ventral side of the vanes of the flight feathers among the birds from family Thamnophilidae in Brazil (Hernandes \& Valim, 2012), which correspond with the findings of this study.

In this study, only one species of tick, Haemaphysalis sp. from the family of Ixodidae was identified. This opportunistic individual of recovered Haemaphysalis sp. was in its larvae stage. Two local studies done in Bangi by Konto et al. (2015) and in Penang by Wahab and Farah Haziqah (2015) reported Haemaphysalis sp. infestations in the jungle fowls (Gallus gallus) and scavenging chickens (Gallus domesticus). According to Godfrey, Moore, Nelson and Bull (2010), the high amount of tick loads might be associated with a form of physiological stress of the host. However, this study shows infrequent detection of tick on the examined birds. This is comparable to most of the existing studies that showed low tick infestations in birds (Brinck, Svedmyr \& von Zeipe, 1965; Jameson, Morgan, Medlock, Watola \& Vaux, 2012; Klaus et al., 2016; Lindeborg et al., 2012). The life cycle of tick involves four phases; egg, larvae, nymph and adult. Most ticks feed on different hosts at each stage of their life and they only spend several days for the blood meals (Klaus et al., 2016) before dropping off from the hosts. This may explain why low tick infestation was accounted in this study.

Some species of ectoparasites were unidentified due to its deteriorate features which was caused by improper handling of this specimen during sorting. Insect 1 can only be identified until order level which is Coleoptera (beetle). This beetle apparently is not parasitizing the birds, but co-inhabiting and preying on the mite and fleas on the birds, as reported among the beetles from family Carabids and Staphylinids (Conn, Carleton, Daniel \& Conn, 2004). There is a possibility that few ectoparasite samples may have been overlooked due to improper handling of the samples. Identification of parasites is a critical phase where specific keys and a basic knowledge on ectoparasite identification are needed. This study provides a preliminary data on the ectoparasite infestations of birds at a rice fields in this region and this study is important as some of the ectoparasites have the potential in transmitting zoonotic diseases to human.

\section{CONCLUSIONS}

This study revealed that rice field in western Sarawak served as harbours for birds and hence supported a diverse species of birds' ectoparasites. In this study, the overall ectoparasites infestation of birds from a rice field at Kuap Village was high with the most common ectoparasite species recovered was Nanopterodectes sp. and the most heavily infested birds with ectoparasites came from the family of Estrildidae and Pycnonotidae. This study has increased the existence understanding of the diversity of ectoparasites of birds from a local rice field. Existing data of avian ectoparasites from rice fields are still insufficient, therefore more studies with greater number of birds from variety of birds should be carried out in future.

\section{ACKNOWLEDGEMENTS}

This project was partially funded by the Malaysia Ministry of Education under Fundamental Research Grant Scheme (FRGS/STG34(02)/963/2013(04)). The authors thank Sarawak Forestry Corporation and Forest Department Sarawak for granting the permission and permit to conduct biological research (Permit No. NPW.907.4.4.(Jld.15)-15 and Park Permit No. WL8/2018). The authors would like to thank the Kuap Village Head and the rice field owners to use their properties for this study. The authors would also like to thank Faculty of Resource Science and Technology, UNIMAS, the administrative and support staff (especially Mr. Wahap Marni, Mr. Shafri Semawi and Mr. Isa Sait) for their field assistance and knowledge throughout the sampling period.

\section{REFERENCES}

Arthur, K. H. M., \& Arthur, J. (1961). On bird species diversity. Ecology, 42(2), 594-598.

Avery, M. L. (1979). Food Preferences and damage levels of some avian rice fields pests in Malaysia. Bird Controls Seminars Proceedings, 22, 161-166.

Bambaradeniya, C. N. B., Fonseka, K. T., \& Ambagahawatte, C. L. (1998). A preliminary study of fauna and flora of a rice field in Kandy, Sri Lanka. Biological Science, 25, 1-22.

Brinck, P., Svedmyr, A., \& von Zeipel, G. (1965). Migrating Birds at Ottenby Sweden as Carriers of Ticks and Possible Transmitters of Tick-Borne Encephalitis Virus. Oikos, 16(1/2), 88-99.

Casas, G., Darski, B., Ferreira, P. M. A., Kindel, A., \& Müller, S. C. (2016). Habitat structure influences the diversity, richness and composition of bird assemblages in successional Atlantic rain forests. Tropical Conservation Science, 9(1), 503-524.

Cheke, R. A. (1972). Birds of the Cherangani Montane forests and their parasites. East African Wildlife Journal, $10,245-249$.

Chuluun, B., Mariana, A., Ho, T., \& Mohd Kulaimi, B. (2005). A preliminary survey of ectoparasites of small mammals in Kuala Selangor Nature Park. Tropical Biomedicine, 22(2), 243-247.

Clayton, D. H., \& Walther, B. A. (1997). Collection and quantification of arthropod parasites of birds. Hostparasite evolution: general principles and avian models, 419-440. 
Clayton. D. H., \& Walther B. A. (2001). Influence of host ecology and morphology on the diversity of Neotropical bird lice. Oikos, 94, 455-467.

Clayton, D. H., Koop, J. A. H., Harbison, C. W., Moyer, B. R., \& Bush, S. E. (2010). How Birds Combat Ectoparasites. The Open Ornithology Journal, 3, 41-71.

Cody, M. L. (1985). Habitat selection in birds. New York: Academic Press.

Conn, S. J., Carleton, R., Daniel, B. R., \& Conn, D. B. (2004). Utilization of Bluebird nest boxes by insects at diverse sites in northeast Georgia. Georgia Journal of Science, 62(1), 1.

Constantinescu, I. C., Chişamera, G., Mukhim, K. B., \& Adam, C. (2016). Feather mites fauna (Acariformes: Analgoidea and Pterolichoidea) of Meghalaya (India). Preliminary data from three scientific expeditions, 23-24.

Department of Agriculture Sarawak. (2016). Potential of Sarawak traditional rice for export. Retrieved November 4, 2017, from http://padi.mardi.gov.my/dokumen/slide/L7\%20Potential\%20of\%20Sarawak\%20Traditional \%20Rice\%20_Datu\%20(DOA\%20Sarawak).pdf.

Diaz-Real, J., Serrano, D., Pérez-Tris, J., Fernández-González, S., Bermejo, A., Calleja, J. A., De la Puente, J., De Palacio, D., Martínez, J. L., Moreno-Opo, R., \& Ponce, C. (2014). Repeatability of feather mite prevalence and intensity in passerine birds. PloS one, 9(9), e107341.

Eadie, J. M., Elphick, C. S., Reinecke, K. J., \& Miller, M. R. (2008). Wildlife values of North American ricelands. In S. W. Manley (Ed.), Conservation in Ricelands of North America (pp. 7-90). Stuttgart, Arkansas: USGS Publications Warehouse.

Fujioka, M., Lee, S. D., Kurechi, M., \& Yoshida, H. (2010). Bird use of rice fields in Korea and Japan. Waterbirds, 33(Special Publication 1), 8-29.

Gillespie T. R., Chapman C. A., \& Greiner, E. C. (2005). Effects of logging on gastrointestinal parasites infection and infection risk in African primates. Journal of Applied Ecology, 42, 699-707.

Godfrey, S. S., Moore, J. A., Nelson, N. J., \& Bull, C. M. (2010). Unravelling causality from correlations: revealing the impacts of endemic ectoparasites on a protected species (tuatara). Parasitology, 137, 275-286.

Hernandes, A. F., \& Valim, P. M. (2012). The genus Nanopterodectes Mironov, 2009 (Acari, Proctophyllodidae), with descriptions of three new species from antbirds (Passeriformes: Thamnophilidae) in Brazil. Systematic Paristology, 83, 227-242.

Hopla, C. E., Durden, L. A., \& Keirans, J. E. (1994). Ectoparasites and classification. Revue scientifique et technique Office international Epizooties, 13(4), 985-1017.

Hung, N. M. (2009). Chewing lice from wild passerines (Aves, Passeriformes) from Vietnam, with description of a new species of the genus Brueelia (Phthiraptera, Ischnocera, Philopteridae). Acta Parasitologica, 54(2), 154-157.

Jameson, L. J., Morgan, P. J., Medlock, J. M., Watola, G., \& Vaux, A. G. (2012). Importation of Hyalomma marginatum, vector of Crimean-Congo haemorrhagic fever virus, into the United Kingdom by migratory birds. Ticks and Tick-Borne Diseases, 3(2), 95-99.

Kevin, K. K. (2012). A study on irrigation efficiency for paddy in Sekuduk Chupak paddy plantation scheme (master's thesis). Universiti Malaysia Sarawak, Kuching, Sarawak.

Klaus, C., Gethmann, J., Hoffmann, B., Ziegler, U., Heller, M., \& Beer, M. (2016). Tick infestation in birds and prevalence of pathogens in ticks collected from different places in Germany. Parasitology Research, 115(7), 2729-2740.

Knee, W., \& Proctor, H. (2006). Keys to the families and genera of blood and tissue feeding mites associated with Albertan birds. Canadian Journal of Arthropod Identification, 2(2), 1-18.

Konto, M., Fufa, G. I., Zakaria, A., Tukur, S. M., Watanabe, M., Ola-Fadunsin, S. D., Khan, M. S., Shettima, Y. M., \& Babjee, S. M. A. (2015). Tick fauna of Malaysian red jungle fowl (Gallus gallus) in Bangi, Malaysia. Veterinary World, 8(10), 1167-1171.

Koop, J. (2015). Darwin's finch species threatened by parasitic flies. Retrieved August 11, 2017, from https://www.seeker.com/darwins-finch-species-threatened-by- parasitic-flies-1770629499.html.

Lindeborg, M., Barboutis, C., Ehrenborg, C., Fransson, T., Jaenson, T. G., Lindgren, P. E., Lundkvist, A., Nyström, F., Salaneck, E., Waldenström, J., \& Olsen, B. (2012). Migratory birds, ticks, and crimean-congo hemorrhagic fever virus. Emerging Infectious Diseases, 18(12), 2095-2097.

Makbul, N. S., \& Wong, A. (2016). The diversity of birds in Kota Belud Bird Sanctuary, Sabah. Journal of Tropical Biology and Conservation, 13, 43-56.

Mariana, A., Zuraidawati, Z., Ho, T. M., Kulaimi, M., Saleh, I., Shukor, M. N., \& Shahrul-Anuar, M. S. (2005). A Survey of Ectoparasites in Gunung Stong Forest Reserve, Kelantan, Malaysia. Southeast Asian Journal of Tropical Medicine and Public Health, 36(5), 1125-1131.

Martins, T. F., Fecchio, A., \& Labruna, M. B. (2014). Ticks of the genus Amblyomma (Acari: Ixodidae) on wild birds in the Brazilian. Systematic \& Applied Acarology, 19(4), 385-392.

Myers, S. (2009). Birds of Borneo: Brunei, Sabah, Sarawak and Kalimantan. Cape Town, South Africa: New Holland Publishers Ltd. 
Nur Munira, A., Nurul Salmi, A. L., Shahrul Anuar, M. S., Mohd Abdul Muin, M. A., Amirrudin, A., \& Nur Juliani, S. (2014). Diversity and temporal distribution of birds in rice-growing landscape, Northern Peninsular Malaysia. Sains Malaysiana, 43(4), 513-520.

Nurqamareena, K., Chong, Y. L., Mohd-Azlan, J., \& Ramji, M. F. S. (2018). A survey of understory birds at a rice field and mixed dipterocarp forest in Kuching, Sarawak. Malaysian Applied Biology Journal, 47(1), 217222.

Phillipps, Q., \& Phillipps, K. (2013). Phillipps' Field Guide to the Birds of Borneo. Oxford, England: John Beaufoy Publishing Ltd.

Sodhi, S., N. (2002). A comparison of bird communities of two fragmented and two continuous southeast Asian rainforests. Biodiversity and Conservation, 11(6), 1105-1119.

Wahab, A. R., \& Farah Haziqah, M. T. (2015). Ectoparasites fauna of scavenging chickens (Gallus domesticus) from Penang Island, Peninsular Malaysia. Malaysian Journal of Veterinary Research, 6(1), 33-42.

Wamiti, S. W. (2014). Diversity and abundance of lice on Speckled Mousebird Colius striatus and Red-capped Lark Calandrella cinerea in two ecologically different habitats in central Kenya. Kenya: Kenyatta University.

Wetmore, A. (1936). The number of contour feathers in passeriform and related birds. Auk, 53, 159-169.

Wood, C. L., Byers, J. E., Cottingham, K. L., Altman, I., Donahue, M. J., \& Blakeslee, A. M. H. (2007). Parasites alter community structure. Proceedings of the National Academy of Sciences, 104(22), 9335-9339. 